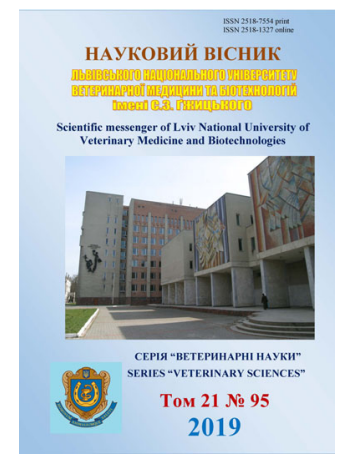

\author{
Науковий вісник Дьвівського націонадьного університету \\ ветеринарної медицини та біотехнологій імені С.З. Гжицького. \\ Серія: Ветеринарні науки \\ Scientific Messenger of Lviv National University \\ of Veterinary Medicine and Biotechnologies. \\ Series: Veterinary sciences
}

UDC: 619:636.8:613.25

\title{
Some indices of the cats' protein metabolism under the obesity
}

\author{
I. Chala, V. Rusak, D. Feshchenko, L. Kovalyova \\ Zhytomyr National Agroecological University, Zhytomyr, Ukraine
}

Article info

Received 03.09.2019

Received in revised form 04.10 .2019

Accepted 05.10.2019

Zhytomyr National Agroecological University, Faculty of Veterinary Medicine; Korolyova Str., 39, Zhytomyr, 10024, Ukraine Tel.: +38-098-274-02-92 E-mail: innachala312@ukr.net
Chala, I., Rusak, V., Feshchenko, D., \& Kovalyova, L. (2019). Some indices of the cats' protein metabolism under the obesity. Scientific Messenger of Lviv National University of Veterinary Medicine and Biotechnologies. Series: Veterinary sciences, 21(95), 36-40. doi: 10.32718/nvlvet9507

Obesity is one of the most widely-distributed metabolic disturbances in cats, herewith the animals' number with a given pathology is constantly increasing. The excess mass and obesity lead to the extreme metabolic disturbances including all the chains of metabolism. The cats belong to wild animals and are characterized by a high level of protein metabolism, herewith they are incapable to keep up with the level of the particular amino acids under their constant introduction into the feeds. The intensity of glucogenesis for which the amino acids are viscous material and are involved into the process of dissemination under the obesity is constantly increasing. It results in increasing the amount of final product of nitrogen metabolism. The paper researches the total protein content as well as that of albumin, ammonia, urine, creatinine and creatine kinase activity of the cats' blood which had the excess mass or obesity. In addition, it has become necessary to determine the content of amino acids cysteine sulfhydryl groups, which essentially contributes to the process of cats' metabolism. To perform the research two groups of cats (female and male) aged 3-7 were formed, the control group consists of 7 clinically healthy animals that corresponds to the BCS 4-5 index according to the nine grading scale, the experimental group consists of 5 animals of the same age and they have BCS - 7-9 index, that testifies to the excess mass and obesity processes. The concentration of the total protein, albumin, ammonia, urine, creatinine as well as of creatine kinase activity of the total and free(nonprotein) sulfhydryl groups was found in the cats' blood. The significant decreasing of the albumin part has been revealed in cats with the excess mass and obesity that causes the liver function disturbances and results in increasing of its protein decomposition. The increasing quality of the ammonia content by $31 \%$ and urine by $21 \%$ has been revealed in cats of the experimental group, however the individual ranges of given indexes within both control and experimental groups were considerable ones. The creatinine concentration and creatine kinase activity in cats with the obesity increases, that testifies to the destructive processes intensification in the muscular tissues. Sulfhydryl groups of the cysteine are of great importance for the metabolic processes in particular in the processes of detoxication, disease-resistance as well as of antioxidant processes. The total concentration of SH-blood groups made no essential difference in cats of the control and experimental groups, while the concentration of free SH-blood groups of experimental animals was by $31 \%$ less than in its control analogues. Thus, the obesity has an essential effects on the protein metabolism that causes the amino acids decomposition processes as well as the accumulation of the metabolic final products and free sulfhydryl groups reducing.

Key words: cat, obesity, blood, ammonia, urine, proteins, sulfhydryl groups.

\section{Деякі показники білкового обміну кішок за ожиріння}

\author{
І.В. Чала, В.С. Русак, Д.В. Фещенко, Л.О. Ковальова
}

Житомирський національний агроекологічний університет, м. Житомир, Україна

Ожиріння - одне з поширених метаболічних порушень у кішок, причому кількість тварин з даною патологією невпинно зростає. Надлишкова маса і ожиріння призводять до глибоких метаболічних порушень, включаючи усі ланки обміну речовин. Кішки є хижаками і характеризуються високим рівнем обміну білків, причому вони не здатні підтримувати рівень певних амінокислот на 
постійному рівні без регулярного їх надходження з кормами. За ожиріння збільшується інтенсивність глюконеогенезу, для якого пластичним матеріалом є амінокислоти, які включаються у прочес дезамінування, в результаті чого зростає концентрація кінцевих продуктів азотистого обміну. Метою роботи було дослідження вмісту загального білка, альбумінів, аміаку, сечовини, креатиніну та активності креатинкінази (КК) крові кішок, щу мали надлишкову масу і ожиріння, також визначали вміст сульфгідрильних груп (SH-) амінокислоти цистеїну (Cys), яка відіграє особливу роль в обміні речовин кімок. Для досліджень сформовано дві групи кішок (самців і самок) віком 3-7 років, контрольна група складалась з 7 клінічно здорових тварин, щуо мали індекс ВСS 4-5 за дев 'ятибальною шкалою, дослідна група включала 5 тварин аналогічного віку і мали BCS - 7-9, щзо є ознакою надлишкової маси $i$ ожиріння. У крові тварин визначали концентрацію загального білка, альбумінів, аміаку, сечовини, креатиніну, активність КК, загальних та вільних (небілкових) SH-груп. В результаті досліджень у кішок з надлишковою масою та ожирінням виявлено достовірне зменшення частки альбумінів, що може бути результатом як порушення функцій печінки, так $і$ зростання розпаду білків. У тварин дослідної групи спостерігалось збільшення вмісту аміаку на 31\% та сечовини - на 21\%, однак індивідуальні коливання даних показників у межах як контрольної, так і дослідної груп були значними. У кішок з ожирінням зростала концентрація креатиніну та активність КК, щео свідчить про інтенсифікацію деструктивних процесів у м'язовій тканині. Сульфгідрильні групи амінокислоти Суs відіграють важливу роль в обмінних процесах, зокрема у процесі детоксикаџії, імунному захисті, антиоксидантних процесах. Загальна концентрація SH-груп крові суттєво не відрізнялась у тварин контрольної та дослідної груп, тимчасом концентрація вільних SH-груп у крові тварин дослідної групи була на 31,3\% меншою, ніж у контрольних аналогів. Таким чином, ожиріння суттєво впливає на білковий обмін, спричиняючи розпад амінокислот, накопичення кінцевих продуктів обміну $і$ зменшення вільних SH-груп.

\section{Ключові слова: кішки, ожиріння, кров, аміак, сечовина, білки, сульфгідрильні групи.}

\section{Ветуп}

Кішки є облігатними хижаками, і тому природно, що їхній раціон має високий рівень тваринного білка. Також для організму котів характерна висока інтенсивність азотного обміну. Разом з тим вони не спроможні підтримувати вміст окремих амінокислот (АМК) на постійному рівні (Backlund et al., 2011). Окрім звичайних амінокислот, що є незамінними для більшості тварин і людини, кішки мають підвищену потребу у швидко дезамінованих АМК цистеїні (Cys) та аргініні (Arg), а також у сульфокислоті таурині (Vasconcellos et al., 2009).

Упродовж останніх десятиліть у хатніх кішок розвиток ожиріння та цукрового діабету, цих “урбаністичних” хвороб-супутників, здобув характеру епізоотії, подібно до аналогічних проблем у людини (Hoenig, 2012; Hoenig, 2014). Як відомо, цим патологіям властиві значні зміни у метаболізмі. Так, розвиток цукрового діабету супроводжується дефіцитом глюкози у тканинах (Flanagan et al., 2018). Водночас деякі вчені вважають, що й видовою особливістю кішок $є$ високі потреби у глюкозі для головного мозку, котрий має порівняно велику масу.

Синтез глюкози може відбуватися декількома метаболічними шляхами. У випадку з ожирінням найактивніше відбувається глюконеогенез - синтез глюкози 3 попередників невуглеводного походження, насамперед 3 АМК у результаті окисного дезамінування (Verbrugohe \& Bakovic, 2013).

Організм котів з різною інтенсивністю використовує окремі АМК, зокрема Суs, який використовується у багатьох біохімічних процесах (Dor et al., 2018). Завдяки наявності вільної сульфгідрильної групи (SH-) Суs входить до складу ферментів, трипептиду глутатіону, використовується для синтезу білка волосся. Окрім того, вуглецеві залишки Суs легко перетворюються у піровиноградну кислоту, а відтак у глюкозу.

Ожиріння призводить до інтенсифікації окислення АМК, зменшення частки м'язової тканини і подальшої гіподинамії тварини. Зростання розщеплення
АМК обумовлює збільшення кількості продуктів азотистого обміну: азоту сечовини, амінного та амонійного, креатиніну (Okada et al., 2017).

Метою даної роботи було дослідити показники залишкового азоту та концентрації сульфгідрильних груп у сироватці крові кішок з надлишковою масою та ожирінням.

\section{Матеріал і методи досліджень}

Дослідження проводились на базі навчальнонауково-виробничої клініки дрібних тварин і кафедри паразитології, ветеринарно-санітарної експертизи та зоогігієни ЖНАЕУ. Були відібрані дві групи кішок віком 3-7 років різної статі й породи. Контрольна група складалась 37 клінічно здорових тварин, котрі проходили діагностичне обстеження перед щепленням. Дослідна група включала 5 кішок, які мали надлишкову масу тіла і ожиріння.

Кондиції тіла кішок оцінювали згідно зі шкалою BCS (body condition score) (Okada et al., 2017). Індекс BCS контрольної групи становив 3 за п'ятибальною шкалою і 4-5 за дев'ятибальною, що відповідає ідеальній масі тварин. BCS кішок дослідної групи становив відповідно - 4-5 і 7-9, що свідчить про ожиріння.

Кров для біохімічних досліджень брали з підшкірної вени передпліччя (v. cephalica antebrachii) 3 дотриманням правил асептики і антисептики. Використовували як цільну кров, що відбирали у вакуумні пробірки із стабілізатором ЕДТА, так і сироватку. У цільній крові визначали загальну концентрацію вільних (небілкових) сульфгідрильних груп з реактивом Еллмана, для чого білки сироватки осаджували 5\% розчином трихлороцтової кислоти, зразки центрифугували та виділяли безбілкову частину сироватки (Meshchyshen \& Hryhorieva, 2002).

У сироватці крові визначали вміст загального білка, альбумінів, сечовини та креатиніну, активність креатинкінази (КФ 2.7.3.2) біохімічним напівавтоматичним аналізатором Chem-7, реактиви лінії DAC, концентрацію аміаку - ферментативним методом (згідно з настановою до набору реактивів) за допомо- 
гою набору реагентів Reagent Set (Ammonia, NHTI A7553-85). В основі ферментативного методу лежить взаємодія аміаку 3 $\alpha$-кетоглутаровою кислотою за наявності НАДФН ${ }_{2}$, у результаті реакції утворюється глутамінова кислота і окиснена форма НАДФ ${ }^{+}$, концентрація останнього продукту прямо пропорційна кількості аміаку, що приєднався до $\alpha$-кетоглутарату. Окислений НАД $\Phi^{+}$зменшує оптичну сорбцію за $\lambda=340$ нм.

Одержані результати опрацьовували Microsoft Excel 2016 з визначенням критерію Стьюдента.

\section{Результати та їх обговорення}

Надлишкова маса тіла у кішок часто призводить до зміщення метаболізму у бік гіперглікемії, а в умовах обмежених запасів вуглеводів - до інтенсивного глюконеогенезу. В результаті, внаслідок дезамінування АМК білків, утворюється аміак, який утилізується переважно у печінці в орнітиновому циклі. Оскільки у кішок ожиріння часто супроводжується певними порушеннями функцій печінки та нирок, важливим є визначення не тільки кінцевого продукту утилізації аміаку - сечовини, а й інтенсивності ії накопичення у крові (Keller et al., 2017). Результати експерименталь- них досліджень деяких показників білкового обміну в кішок наведені в таблиці.

Як видно з таблиці, уміст загального білка сироватки крові кішок в обох групах суттєво не відрізнявся і перебував у референтних межах. Разом $з$ тим спостерігалась статистично достовірна різниця між вмістом альбумінів (АЛБ). Так, у кішок контрольної групи частка цієї фракції становить 51,78\%, а у тварин дослідної групи - лише 25,22\%. Як відомо, АЛБ є резервом АМК і синтезуються печінкою; зменшення їх частки може бути наслідком зниженням синтезу білків печінкою тварин 3 ожирінням або зростанням інтенсивності катаболізму АЛБ.

Кінцевим продуктом розпаду азотовмісних сполук $\epsilon$ аміак. Однак його концентрація у крові досить низька, оскільки це надзвичайно токсичний метаболіт. Існує спеціальний механізм транспорту аміаку з тканин до печінки за участю глутамінової кислоти. При збільшенні пулу аміаку у тканинах зростає його вихід у кров у вільному стані (Pablack \& Zentek, 2018). Концентрація аміаку в крові кішок дослідної групи незначно перевищувала верхню фізіологічну межу і була на 31\% більшою, ніж контрольні значення. Уміст сечовини у крові дослідних кішок мав тенденцію до підвищення $(+20,95 \%)$.

\section{Таблиця}

Зміни показників білкового обміну у крові кішок з надлишковою масою тіла та ожирінням, $\mathrm{M} \pm \mathrm{m}$

\begin{tabular}{lcc}
\hline \multicolumn{1}{c}{ Показник } & Контрольна група, $\mathrm{n}=7$ & Дослідна група, $\mathrm{n}=5$ \\
\hline Загальний білок, г/л & $64,5 \pm 7,37$ & $68,2 \pm 8,71$ \\
Альбуміни, г/л & $33,4 \pm 3,78$ & $17,2 \pm 3,85^{*}$ \\
Сечовина, ммоль/л & $8,3 \pm 1,27$ & $10,1 \pm 1,48$ \\
Креатинін, мкмоль/л & $97,9 \pm 10,32$ & $122,6 \pm 15,43$ \\
Креатинкіназа, Од/л & $185,2 \pm 21,62$ & $265,9 \pm 42,70$ \\
Аміак, мкмоль/л & $47,7 \pm 5,83$ & $62,5 \pm 8,25$ \\
\hline Примікк $:$ - різниця між показниками у тварин контрольної та дослідної груп на рівні $\mathrm{P}<0,05$
\end{tabular}

Примітка: * - різниця між показниками у тварин контрольної та дослідної груп на рівні $\mathrm{P}<0,05$

Різниця між означеними показниками може свідчити про неспроможність печінки у повному обсязі утилізувати аміак. Отже, супутніми симптомами ожиріння є гепато- та нефропатії (Marino et al., 2014).

Критерієм, що характеризує фільтрувальну здатність нирок, $є$ вміст креатиніну. Також креатинін $є$ показником інтенсивності катаболізму м'язових білків, які є резервом АМК у процесі глюконеогенезу. У кішок дослідної групи концентрація цього метаболіту мала тенденцію до зростання $(+25,2 \%)$, що свідчить про інтенсивне використання енергетичного резерву м'язів за ожиріння.

Креатинін $є$ продуктом неферментативного окислення креатину, його концентрація залежить від енергетичного обміну. 3 метою встановлення можливих цитолітичних процесів у м'язах хворих кішок ми визначали активність креатинкінази (КК, креатинфосфокінази). Вказаний фермент локалізується у скелетних м'язах, міокарді та головному мозку, однак основна частка його активності в сироватці крові припадає на м'язовий ізофермент (Kawasumi et al., 2018). Таким чином, зміна активності КК може свідчити про порушення цілісності м'язових клітин і розпад білків. Ак- тивність КК у крові кішок з ознаками ожиріння була на $45,7 \%$ вищою, ніж у контрольних тварин. Таким чином, збільшення концентрації креатиніну і активності КК свідчить про зменшення частки м'язової тканини за умов накопичення жиру.

Сульфгідрильні групи (SH-) є складовою частиною Cys (Morris \& Rogers, 1978; Nguyen et al., 2002). Кішкам властива підвищена потреба у Суs для синтезу білків волосяного покриву та феромону фелініну. Окрім того, у них вкрай низька активність ферментних систем, які синтезують АМК таурин 3 Суs (Shulatkina et. al., 2012). При ожирінні важливою $€$ участь Суs у формуванні глутатіону та підтриманні вторинної структури інсуліну.

Концентрацію загальної кількості SH-груп визначали у цільній крові, а вільні SH-групи, які представлені переважно вільним Суs, - у безбілковій частині сироватки крові (рис. 1).

У кішок $з$ ожирінням спостерігалась тенденція до зменшення $(-10,2 \%)$ загальної концентрації SH-груп у крові, порівняно зі здоровими тваринами $(132,0 \pm 15,6$ і 147,0 \pm 16,8 ммоль/л відповідно). 


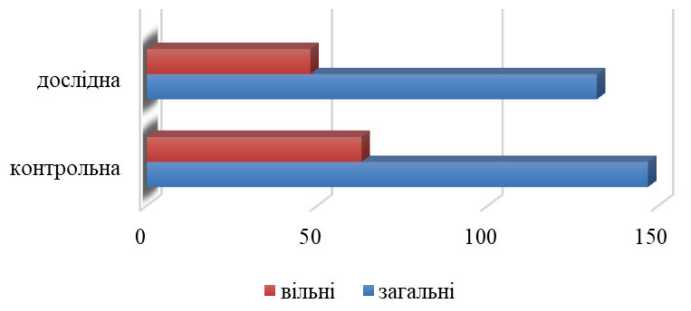

Рис. 1. Концентрація загальних і вільних SH-груп у крові кішок з ожирінням, ммоль/л

Аналогічна тенденція прослідковувалась й відносно концентрації вільних SH-груп і складала: в дослідній групі - 48,0 $\pm 6,3$, а в контрольній $-63,0 \pm$ 10,1 ммоль/л (-31,3\%). Отже, суттєвих змін у загальному вмісті SH-груп за ожиріння кішок не спостерігалось. Водночас зниження концентрації вільних $\mathrm{SH}-$ груп, не зв'язаних з білками, була суттєвою, хоча і статистично недостовірною.

Таким чином, у кішок з ожирінням виникає певний дефіцит вільних SH-груп, які відіграють важливу роль у процесах детоксикації. Це негативно впливає на розвиток компенсаторних механізмів, які забезпечують відновлення метаболічних порушень, викликаних надлишковою масою та ожирінням.

\section{Висновки}

Надлишкова маса та ожиріння у кішок призводять до зростання катаболічних процесів, дезамінування АMК і накопичення кінцевих продуктів обміну білків, про що свідчить зменшена частка АБМ і збільшена концентрація аміаку та сечовини. Підвищена активність КК та накопичення креатиніну в крові хворих кішок свідчить про розвиток деструктивних змін у м'язах і порушення функціональної активності нирок. Зниження кількості загальних і вільних SH-груп за ожиріння у котів є результатом надмірної втрати Cуs.

Перспективи подальших досліджень. Плануються дослідження вмісту амінокислот Arg i Cys, а також визначення різних фракцій ліпідів у крові кішок 3 ожирінням та цукровим діабетом.

\section{References}

Backlund, B., Zoran, D.L., Nabity, M.B., Norby, B., \& Bauer, J.E. (2011). Effects of Dietary Protein Content on Renal Parametrs in Normal Cats. Journal of Feline Medicine \& Surgery, 13, 698-704. doi: 10.1016/jfms2011.05.019.

Chala, I.V., Zghozinska, O.A., Rusak, V.S., Chuprun, L.O., \& Kovalov, P.V. (2018). Zminy stanu hlutationovoi systemy krovi kotiv za tsukrovoho diabetu ta ozhyrinnia. Naukovyj visnyk LNUVMB imeni S.Z. G'zhyc'kogo. Serija: Veterynarni nauky, 20(88), 125-130. doi: 1032718/nvlvet8823 (in Ukrainian).

Dor, C., Adamany, J.L., Kisielewicz, C., de Brot, S., Erles, K., \& Dhumaeux, M.P. (2018). Acquired Urea Cycle Amino Acid Deficiency and Hyperammonaemic Encephalopathy in a Cat with Inflammatory Bowel Disease and Chronic Kidney Disease. Journal of Fe- line Medicine \& Surgery. Open Reports, 4(2). doi: $10.1177 / 2055116918786750$.

Flanagan, J., Bissot, T., Hours, M.A., Moreno, B., \& German, A.J. (2018). An International Multi-Centre Study of Weight Loss in Overweight Cats: Differences in Outcome in Different Geographical Locations. Journal PLoS One, 13(7), e0200414. doi: 10.1371/jornal.pone.0200414.

Hoenig, M. (2012). The Cat as a Model for Human Obesity and Diabetes. Journal of Diabetes Science \& Technology, 6(3), 525-533. doi: 10.1177/193229681200600306.

Hoenig, M. (2014). Comparative Aspects of Human, Canine and Feline Obesity and Factors Predicting Progression to Diabetes. Journal of Veterinary Science, 1, 121-135. doi: 10.3390/vetsci1020121.

Kawasumi, K., Murai, T., Mizorogy, T., Okada, Y., Yamamoto, I., Suruga, K., Kadokura, K., \& Arai, T. (2018). Changes in Plasma Metabolites Concentrations in Obese Dogs Supplemented with Anti-oxidant Compound. Journal of Frontiers in Nutrition, 5, 74 80. doi: 10.3389/fnut.2018.00074.

Keller, C., Liesegang, A., Frey, D., \& Wichert, B. (2017). Metabolic Response to Three Different Diets in Lean Cats and Cats Predisposed Overweight. BMC veterinary research, 13, 184-191. doi: 10.1186/s12917-0171107-3.

Marino, L.C., Lascelles, B.D.X., Vaden, S.L., Gruen, M.E., \& Marks, S.L. (2014). The Prevalence and Classification of Chronic Kidney Disease in Cats Randomly Selected within Four Age Groups and in Cats Recruited for Degenerative Joint Disease Studies. Journal of Feline Medicine \& Surgery, 16, 465-472. doi: 10.1177/1098612X13511446.

Meshchyshen, I.F. \& Hryhorieva, N.P. (2002). Metody kilkisnoho vyznachennia SH-hrup u krovi. Bukovyns'kyj medychnyj visnyk, 6(2), 190-192 (in Ukrainian).

Morris, J.G., \& Rogers, Q.R. (1978) Arginine: An Essential Amino Acid for the Cat. Journal of Nutrition. 108(12), 1944-1055. doi: 10.1093/jn/108.12.1944.

Nguyen, P., Dumon, H., Martin, L., Siliart, B., Ferreier, L., Humbert, B., Diez, M., Breul, S., \& Biourge, V. (2002). Weight Loss does not Influence Energy Expenditure or Leucine Metabolism in Obese Cats. Journal of Nutrition, 132(6), 1649-1651. doi: 10/1093/jn/132.6.1649S.

Okada, Y., Kobayashi, M., Sawamura, M., \& Arai, T. (2017). Comparison of Visceral Fat Accumulation and Metabolome Markers among Cats of Varying BCS and Novel Classification of Feline Obesity and Metabolic Syndrome. Frontiers in Veterinary Science, 4, 17. doi: $10.3389 /$ fvets.2017.00017.

Pablack, N., \& Zentek, J. (2018). Effects of Dietary Arginine, Ornithine and Zeolite Supplementation on Uremic Toxins in Cats. Toxins (Basel), 10(5), 206-218. doi: 10.3390/toxins10050206.

Shulatkina, A.V., Peshev, L.P., \& Ljalichkina, N.A. (2012). Modifikacii al'buminov i sul'fgidril'nyh grupp krovi u zhenshhin s hronicheskoj venoznoj nedostatochnost'ju. Sovremennye problemy nauki i obrazovani- 
ja, $\quad$ 6. URL: $\quad$ http://www.scienceeducation.ru/ru/article/view?id=7887 (in Russian).

Vasconcellos, R.S., Borges, N.C., Gonçalves, K.N.V., Canola, J.C., de Paula, F.J.A., Malheiros, E.B., Brunetto, M.A., \& Carciofi, A.C. (2009). Protein Intake during Weight Loss Influences the Energy Required for Weight Loss and Maintenance in Cats. Journal of Nutrition, 139, 855-860. doi: 10.3945/jn.108.103085. Verbrugohe, A., \& Bakovic, M. (2013). Peculiarities of One-Carbone Metabolism in the Strict Carnivorous Cat and Role in Feline Hepatic Lipidoses. Journal of Nutrition, 5(7), 2811-2835. doi: 10.3390/nu5072811. 